\title{
Role of vitamin D in treating COVID-19-associated coagulopathy: problems and perspectives
}

\author{
Tanusree Sengupta $^{1}$ [ $\cdot$ Rinku Majumder ${ }^{2} \cdot$ Samarpan Majumder ${ }^{3}$
}

Received: 27 August 2020 / Accepted: 29 January 2021 / Published online: 18 February 2021

(c) The Author(s), under exclusive licence to Springer Science+Business Media, LLC part of Springer Nature 2021

\begin{abstract}
Aggressive inflammatory response leading to hypercoagulability has been found to be associated with disease severity in COVID-19 patients and portends bad treatment outcome. A state of acute disseminated intravascular coagulation (DIC), along with pulmonary embolism and/or deep vein thrombosis, has been observed in critically ill ICU patients. Autopsy reports of COVID-19 patients demonstrated microthrombi in lungs and in other organs, as well as marked inflammatory changes, characteristic clinicopathological features that exacerbate disease severity. Vitamin D supplementation was recommended by many clinicians across the globe to improve clinical symptoms of COVID-19 patients, mainly because of its immunomodulatory roles on immune cells. Furthermore, vitamin D and its associated molecules are also known to directly or indirectly regulate various thrombotic pathways. We propose that vitamin D supplementation not only attenuates the risk of Acute Respiratory Disease Syndrome (ARDS) but it also may have a role in reducing coagulation abnormalities in critically ill COVID-19 patients. The overarching goal of this review is to discuss the effects of vitamin D on coagulation pathways and other intertwined processes leading to thrombosis. Many clinical trials are currently investigating the efficacy of vitamin D supplementation in reducing the risk of COVID-19 infection. However, randomized placebo control clinical trials are also necessary to ascertain the effect of vitamin D supplementation on reducing the risk of coagulopathy in COVID-19 patients.
\end{abstract}

Keywords Vitamin D · COVID-19 · Coagulation · Inflammation · Hypercoagulability · Thromboinflammation ·

Thrombosis $\cdot$ Venous thromboembolism (VTE)

\section{Introduction}

The COVID-19 pandemic is not only different from earlier Severe Acute Respiratory Syndrome (SARS) or Middle East Respiratory Syndrome (MERS) in terms of sheer number of fatalities, but COVID-19 is also fascinating because of the wide spectrum of clinical symptoms it manifests. Progressive hypoxemia, respiratory failure, ARDS, and multi-organ failure have all been identified as major causes of mortality

Tanusree Sengupta

tanusrees@ssn.edu.in

Samarpan Majumder

smaju1@1suhsc.edu

1 Department of Chemistry, Sri Sivasubramaniya Nadar College of Engineering, Chennai, India

2 Department of Biochemistry \& Molecular Biology, LSU Health Science Center, New Orleans, USA

3 Department of Genetics, LSU Health Science Center, New Orleans, USA due to COVID-19. Abnormal coagulation parameters such as elevated level of circulating D-dimer and fibrinogen [1] are commonly observed in critically ill COVID-19 patients, indicating hypercoagulability as a poor prognosis of the disease [2-5]. Inflammation as part of innate and adaptive immunity during an infection triggers activation of coagulation. Activation of coagulation, in turn, markedly affects the inflammatory activity [6]. Extensive crosstalk between the two systems is associated with the formation of microvascular thrombi often leading to organ dysfunction in severe sepsis [7].

Inflammation-induced activation of coagulation is operated through three main mechanisms-tissue factor (TF)mediated thrombin generation, downregulation of anticoagulant pathways, and impairment of fibrinolytic system [6]. More and more TF is released in circulation when vessel wall is disrupted by infection. Concurrently, endothelial cells and monocytes also start expressing TF in response to various proinflammatory cytokines (such as TNF- $\alpha$, IL-1, IL-6, IL-8, and MCP-1). Once TF is exposed to blood, coagulation 
is initiated to produce thrombin, fibrinogen, and fibrin. Thrombin is involved in the feedback activation of coagulation by stimulating coagulation factors V, VIII, XI, and XII. It also activates platelet causing platelet aggregation and clot formation. Activated coagulation factor $\mathrm{X}$ and thrombin along with fibrin and fibrinogen, on the other hand, induce the synthesis and release of inflammatory cytokines (IL-6 and/or IL-8) enabling activation of inflammatory system. The coagulation-induced inflammation, again, impairs the anticoagulant pathway leading to a coagulant-anticoagulant imbalance and enhances the risk of thrombosis. The coordinated activation of inflammatory and hemostatic responses, termed thromboinflammation [8], is well characterized for viral, bacterial or fungal infection. The increased level of IL-6 along with D-dimer and fibrinogen in severely ill COVID-19 patients reported by different groups confirms the occurrence of thromboinflammation in SARS-CoV-2 infection as well, suggesting hypercoagulability driven by the cytokine storm and associated hypoxemia leads to severe thromboembolic complications in COVID-19 [9-11]

Several groups have reported that increased vitamin D level plays a beneficial role in the recovery of COVID-19 patients. Vitamin D, a steroid hormone, exists in our body in two different forms: vitamin D2 and vitamin D3. Both forms get metabolized first to 25 hydroxyvitamin $\mathrm{D}[25(\mathrm{OH})$ $\mathrm{D}]$, and then to 1,25 -dihydroxyvitamin $\mathrm{D}\left[1,25(\mathrm{OH})_{2} \mathrm{D}\right]$, to become active. It has been observed that vitamin D3 is more efficacious at raising concentrations of serum $25(\mathrm{OH}) \mathrm{D}$ than D2. The active forms of vitamin D bind to vitamin D binding protein (VBP) and get transported to the required organs to be presented as a natural ligand to vitamin $\mathrm{D}$ receptors (VDR). VDR is a member of a nuclear hormone receptor family and is widely distributed across all the tissues controlling hundreds of genes responsible for the regulation of cellular proliferation, differentiation, apoptosis, and angiogenesis [12]. Therefore, apart from its traditional role in maintaining skeletal health and calcium and phosphorous homeostasis, the active metabolites of vitamin $\mathrm{D}$ are believed to regulate diverse biological processes. Various vitamin $\mathrm{D}$ analogs are used to treat hyperproliferative disorders such as psoriasis and cancer, secondary hyperparathyroidism accompanying renal failure, immunological disorders, etc.

The protective role of vitamin D against COVID-19 disease severity has been attributed mostly to the impact it has on the immune system. Vitamin D restricts the production of inflammatory cytokines and inhibits the proliferation of proinflammatory cells, both of which are crucial for the pathogenesis of inflammatory diseases. Vitamin $\mathrm{D}$ was also reported to enhance the ratio of angiotensinconverting enzyme 2 (ACE2) to ACE and thereby reducing the level of angiotensin II level by hydrolyzing the enzyme [13]. Altogether these effects are indicative of beneficial effects of vitamin D supplementation in decreasing the risk and adverse outcomes of acute lung injury associated with COVID-19. Interestingly, vitamin D and its associate molecules also have a substantial effect on coagulation pathways attenuating thrombosis [14]. Therefore, we hypothesize that vitamin $\mathrm{D}$ could be considered as a crucial nutrient in reducing thromboinflammation associated with COVID-19 and thus may expedite the recovery from the disease. The current review will discuss the potential role of vitamin $D$ to combat coagulopathy, a defining hallmark leading to severity of the disease due to SARS-COV-2 infection.

\section{Vitamin D and COVID-19}

It has been suggested by several studies that vitamin D deficiency can contribute to the severity and mortality of SARS-CoV 2 infection. The fatality of the disease increases with increasing age and comorbidity (diabetes, renal disorder, hypertension) of the infected person [15-17], both of which can be associated with vitamin D deficiency [18-20]. Deficiency of vitamin D is generally observed in individuals above 70 years due to decreased sun exposure and subcutaneous synthesis. Several studies have also reported that people with chronic diseases have lower $25(\mathrm{OH}) \mathrm{D}$ concentrations than it is in healthy people. Although there is no consensus on the optimal level of vitamin D, the European Calcified Tissue Society Working Group has defined severe vitamin D deficiency as a serum $25(\mathrm{OH}) \mathrm{D}$ level lower than $30 \mathrm{nmol} / \mathrm{L}$ [21]. A study in Italy reported that male chronic obstructive pulmonary disease patients had a mean $25(\mathrm{OH})$ D concentrations of 16 (95\% CI 13-18) $\mathrm{ng} / \mathrm{mL}$, whereas female patients had concentrations of 13 (95\% CI 11-15) ng/ $\mathrm{mL}$ [22]. A study in South Korea reported that communityacquired pneumonia (CAP) patients had a mean 25(OH)D concentration of $14 \pm 8 \mathrm{ng} / \mathrm{mL}$ at hospital admission [23]. A study in Iran reported that hypertensive patients had lower $25(\mathrm{OH}) \mathrm{D}$ concentration [24].

Ilie et al. [25] found a crude association between the mean vitamin D levels in various European countries with COVID-19 cases and COVID-19 mortality. Laird et al. [26] demonstrated that the correlation between $25(\mathrm{OH}) \mathrm{D}$ concentration and COVID-19 mortality rate is statistically significant $(P=0.046)$ by Spearman's Rank Correlation. Rastogi et al. conducted a randomized placebo-controlled study on hospitalized COVID-19 patients to evaluate the effect of vitamin D (cholecalciferol) supplementation on disease severity [27]. A significant proportion of COVID19-infected patients were tested RNA negative after the cholecalciferol dose. Fibrinogen level was also observed to be decreased for them. In another pilot study, Castillo et al. showed that administration of high dose of calcifediol to the patients reduced the need for ICU treatment 
appreciably [28]. Brigham and Women's Hospital along with Harvard Medical school and other collaborators is conducting a nationwide randomized clinical trial (Clinical Trials.gov Identifier: NCT04536298) in 2700 U.S. men and women to investigate whether taking a daily dietary supplement of vitamin D for 4 weeks reduces the risk of hospitalization and/or death in participants newly diagnosed with COVID-19. The study, which is supposed to be completed in March 2021, will also examine whether the vitamin dose reduces the risk of infection with severe acute respiratory syndrome coronavirus 2 (SARS-CoV-2) in their closest household contacts. Phase 3 randomized controlled trial with 6200 enrolled participants is also going on to check the effect of Vitamin D Supplementation to Reduce Risk and Severity of COVID-19 and Other Acute Respiratory Infections in the UK (Clinical Trials.gov Identifier: NCT04579640). These studies posit crucial role of vitamin D in reducing the risk COVID-19 severity and many countries are actually recommending vitamin D supplementation. World Health Organization recommends a daily intake of $5 \mu \mathrm{g}$ (200 IU) for adults and $15 \mu \mathrm{g}$ (600 IU) for individual over 65 years. A high-dose $(250,000$ or $500,000 \mathrm{IU})$ vitamin D3 trial conducted during 2011-2014 on ventilated intensive care unit patients reported an increase in plasma vitamin $\mathrm{D}$ level and a reduction in the length of hospital stay for the patients without altering other clinical outcomes [29]. Currently, more clinical trials are needed to determine the safety and efficacy of optimum high dose, since high dose of vitamin D may also result in significantly lower bone mineral density [30].

\section{Vitamin D and inflammation}

As mentioned earlier, the possible link between vitamin D deficiency and COVID-19 is being attributed, by and large, to the impact it has on the inflammatory response (Fig. 1). CYP27B1, the key enzyme involved in the conversion of vitamin D to its active form, and VDR are both expressed in macrophages, dendritic cells (DC), and T lymphocytes. These cells are involved in mediating key immune/inflammatory response, which provides the biological basis for the role of vitamin D in inflammatory diseases [12]. In macrophages, activation of the toll-like receptor (TLR1/2) heterodimer results in the upregulation of VDR and CYP27B1, leading to induction of the antimicrobial peptide cathelicidin. Cathelicidin exhibits direct antimicrobial activity against a spectrum of microbes, including enveloped and non-enveloped viruses [31]. Thus, vitamin D can potentiate the cellular innate immunity.

Both forms of vitamin $\mathrm{D}-1,25(\mathrm{OH})_{2} \mathrm{D}$ and $25(\mathrm{OH})$ $\mathrm{D}$-have been found to block LPS-induced p38 signaling to deactivate cytokine (IL- 6 and TNF $\alpha$ ) production in monocytes/macrophages [32]. The active form of vitamin D or its analogs have been shown to reduce MCP-1 and IL-6 expression by blocking the activation of NF- $\mathrm{\kappa B}$ in macrophages [33]. Moreover, vitamin D is a natural endoplasmic reticulum stress reliever, and can selectively suppress key effector functions of interferon (IFN)- $\gamma$-activated macrophages [34, 35]. $1,25(\mathrm{OH})_{2} \mathrm{D}$ inhibits the differentiation, maturation, and immunostimulatory capacity of human antigen presenting DC in a VDR-dependent manner causing the induction of T-regulatory cells, a critical event for suppressing the inflammatory response of T-effector cells. It has also been revealed that $1,25(\mathrm{OH})_{2} \mathrm{D}$ inhibited the production of proinflammatory cytokines, including IFN $\gamma$, IL-17, and IL-21

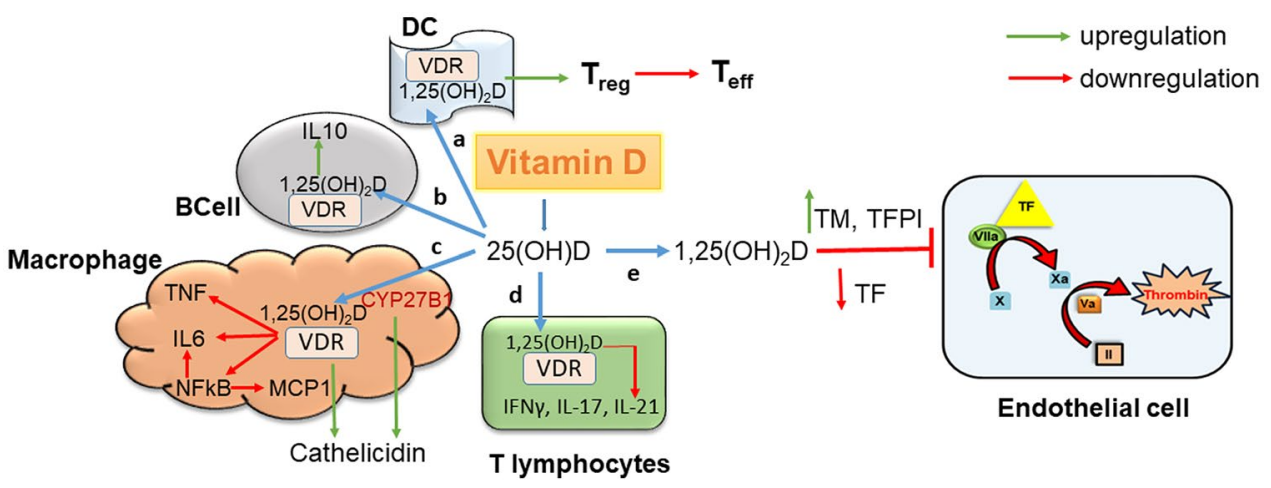

Fig. 1 Vitamin D as an anti-inflammatory and anti-thrombotic agent. Active metabolite of vitamin D (a) suppresses the inflammatory response of T-effector cell by inhibiting the maturation and activity of DCs in VDR-dependent manner; (b) activates the production of antiinflammatory IL-10 in B cell; (c) downregulates TNF, IL-6, NFkB,
MCP-1 and activates the antimicrobial peptide cathelicidin in macrophages; (d) downregulates IFN $\gamma$, IL-17, and IL-21 in T lymphocytes; (e) upregulates the natural anticoagulants TM and TFPI and deactivates $\mathrm{TF}$ and thereby reduces hypercoagulability 
[36]. Notably, while decreasing the expression of proinflammatory cytokines in airway SMCs, vitamin D has been found to increase the production of IL-10, an anti-inflammatory cytokine, thereby, minimizing the deleterious effects of inflammatory cytokines [37]. Further, vitamin D also helps to maintain tight junctions, gap junctions, and adherent junctions, which are often disrupted by different virus and other pathogens increasing the extent of infection [38].

\section{Regulation of thrombotic disorders by vitamin $D$}

Vitamin D metabolites have emerged as an effective anticoagulant as is reflected in its ability to regulate different proand anti-thrombotic agent of coagulation cascade (Fig. 1). It upregulates antigen expression, activity, and mRNA levels of an anticoagulant, thrombomodulin (TM), and downregulates antigen expression, activity, and mRNA levels of the crucial prothrombotic factor, TF, that initiates the activation of coagulation [39]. Similar regulatory effects on TF and TM were also reported for KY3 and 22-oxacalcitriol, two synthetic analogs of the active vitamin D metabolites, mediated through VDR [40]. These agents could be used as a potential therapeutics for the treatment of atherosclerotic and other cytokine-mediated thrombotic diseases. Addition of vitamin D molecule calcitriol $\left(1,25(\mathrm{OH})_{2} \mathrm{D} 3\right)$ and paricalcitol (19-nor-1,25-(OH) $\left.{ }_{2} \mathrm{D} 2\right)$ has been found to reduce TNF- $\alpha$-induced expression and activity of TF in vascular smooth muscle cells by downregulation of NF- $\mathrm{kB}$ signaling and PAR-2 expression [41]. This was accompanied by the upregulation of tissue factor pathway inhibitor (TFPI) expression and restoration of VDR level. A separate study also reported a significant positive correlation between TFPI level and serum 25(OH)D3 level [42].

The anti-thrombotic property of vitamin D was further substantiated by several clinical studies that correlated vitamin D deficiency with thrombosis (Table 1). Low levels of $25(\mathrm{OH}) \mathrm{D}$ were found to be associated with idiopathic lower-extremity deep vein thrombosis (DVT) as observed in a group of 82 patients [43]. Sub-physiological levels of vitamin D were also predictive of DVT in patients with ischemic stroke [44]. A study from Switzerland reported a reduction in thrombin generation and decreased clot density with high-dose cholecalciferol supplementation, without any change in fibrinolytic times for patients with severe vitamin D deficiency [45]. Beer et al. [46], in a placebo-controlled randomized trial of the high-dose of $1,25(\mathrm{OH})_{2} \mathrm{D} 3$, showed significantly reduced numbers of thrombotic events in cancer patients. In order to explain the seasonal variation of risk of VTE (risk is greater in winter than summer), Lindqvist et al. [47] sought a possible correlation between sun exposure habits and occurrence of VTE. The cohort study, comprising 40,000 women followed for $\sim 11$ years, revealed intriguing aspects about the link between vitamin $\mathrm{D}$ and thrombosis; Swedish women having greater exposure of sun were at $30 \%$ lower risk of VTE than those who did not. Data looked statistically significant even after accounting for demographic variables. Greater sun exposure must have improved the vitamin D status which was manifested

Table 1 Clinical trials correlating vitamin D deficiency with elevated risk of thrombosis

\begin{tabular}{|c|c|c|c|c|}
\hline Study & Sample size & $\begin{array}{l}\text { Clinical feature/ coagulation } \\
\text { parameter }\end{array}$ & Findings & Conclusions \\
\hline Blondon et al. (2019) [41] & 48 & Prothrombotic profile & $\begin{array}{l}\text { Vitamin D supplementa- } \\
\text { tion resulted in decrease in } \\
\text { thrombin generation }\end{array}$ & $\begin{array}{l}\text { Severe vitamin D deficiency } \\
\text { might be associated with a } \\
\text { potentially reversible pro- } \\
\text { thrombotic profile }\end{array}$ \\
\hline Wu et al. (2018) [40] & 180 & $\begin{array}{l}\text { DVT in patients with history } \\
\text { of ischemic stroke }\end{array}$ & $\begin{array}{l}\text { Serum vitamin D levels were } \\
\text { significantly lower in the } \\
\text { DVT group than in the non- } \\
\text { DVT group }\end{array}$ & $\begin{array}{l}\text { Low vitamin D level is inde- } \\
\text { pendent predictor of DVT }\end{array}$ \\
\hline $\begin{array}{l}\text { Khademvatani et al. (2014) } \\
\text { [39] }\end{array}$ & 275 & DVT & $\begin{array}{l}68.3 \% \text { population in DVT } \\
\text { group was vitamin D defi- } \\
\text { cient }\end{array}$ & $\begin{array}{l}\text { Vitamin D deficiency is associ- } \\
\text { ated with idiopathic lower- } \\
\text { extremity DVT }\end{array}$ \\
\hline Lindqvist et al. (2009) [43] & 40,000 & VTE & $\begin{array}{l}\text { Women with greater exposure } \\
\text { of sun have } 30 \% \text { lower risk } \\
\text { of having VTE }\end{array}$ & $\begin{array}{l}\text { Greater exposure of sunlight } \\
\text { improves vitamin D status } \\
\text { of a person resulting in the } \\
\text { enhancement of anticoagulant } \\
\text { property }\end{array}$ \\
\hline Beer et al. (2006) [42] & 250 & Thrombosis in cancer patients & $\begin{array}{l}\text { Events of thrombosis was only } \\
2 \text { in patients given calcitriol } \\
\text { compared to } 11 \text { in placebo- } \\
\text { treated control }\end{array}$ & $\begin{array}{l}\text { High dose of vitamin D reduced } \\
\text { thrombosis in cancer patients }\end{array}$ \\
\hline
\end{tabular}


in the reduced risk of VTE. Moreover, a pilot clinical trial reported an enhancement of anticoagulant effect of warfarin by vitamin D supplementation [48].

Considerable amount of clinical and experimental data indicated the potential role of vitamin $\mathrm{D}$ in reducing the risk of inflammatory diseases and coagulopathy. Therefore, it became evident that intake of vitamin D could be beneficial in reducing the severity of COVID-19 infection not only due to its anti-inflammatory property but also due to its anticoagulant property.

\section{Future perspective}

The deleterious effect of so-called "cytokine storm" and hypoxia causes an increased incidence of venous thromboembolism (VTE) due to induction of COVID-19-associated coagulopathy in ICU patients $[49,50]$. Therefore, all confirmed or suspected COVID-19 patients admitted to the hospital are advised to be treated with pharmacologic VTE prophylaxis, given the high inflammatory state, unless there are specific contraindications [4]. So far, no specific antiviral therapy is available to combat the underlying infection causing hypercoagulability. Notably, increased survival benefit of systematic anticoagulant therapy in severe COVID-19 patients has been reported by many groups [51, 52]. Low molecular weight heparin (LMWH), fondaparinux, nadroparin, warfarin, etc. were frequently used to mitigate hypercoagulability. However, the risk of bleeding episodes remains a concern and patients require constant monitoring [53].

Connors et al. [4] suggested that dose of anticoagulant therapy for COVID-19 patients should be decided after carefully assessing the bleeding risk for each patient. This hemorrhagic complications of anticoagulant therapy could be avoided using a lower dose of anticoagulant supplemented with vitamin D. Vitamin D could be an effective agent in reducing bleeding disorders in patients receiving anticoagulant therapy. Hejazi et al. [48] showed that vitamin D supplementation begat the possibility of lower dosing regimen of warfarin and was associated with less adverse reaction in patients with thromboembolism. However, the authors concluded that due to small sample size of the study population, their expected clinical endpoint did not meet statistical significance.

Notably, Lemke et al. [51] argued that the abnormal coagulation in severe COVID-19 patients is "consumptive". The authors also suggested that along with the depletion of important coagulation factors, clinical manifestation of abnormal clotting in many critical COVID-19 patients also consumes an essential anticoagulant, protein S. Indeed, in a cohort study performed in Colentina University Hospital, Romania, protein S level was observed to be decreased in COVID-19 patients [54]. Therefore, any augmentation of anticoagulant effect by vitamin $\mathrm{D}$ should have a favorable outcome in those patients. It would be interesting to initiate clinical trials of COVID patients on anticoagulant therapy with and without vitamin D supplementation to tease out the subtle efficacy of vitamin D in such treatment setting.

\section{Conclusion}

The current review therefore concludes that inclusion of vitamin D supplementation along with prophylactic dose of anticoagulant has a tremendous potential as a combinatorial treatment regimen to treat COVID-19-associated coagulopathy. Double-blinded randomized placebo-controlled clinical trial is warranted to explore the efficacy of vitamin D supplementation in reducing severity and mortality of COVID-19 due to thrombotic complications.

Funding DST-SERB (Department of Science \& Technology-Science and Engineering Research Board, Govt. of India) Project No. DST/ ECR/2017/000447 to TS.

\section{Compliance with ethical standards}

Conflict of interest Authors declare no conflict of interest.

\section{References}

1. Tang N, Li D, Wang X, Sun Z (2020) Abnormal coagulation parameters are associated with poor prognosis in patients with novel coronavirus pneumonia. J Thromb Haemost 18(4):844-847. https://doi.org/10.1111/jth.14768

2. Panigada M, Bottino N, Tagliabue P, Grasselli G, Novembrino C, Chantarangkul V, Pesenti A, Peyvandi F, Tripodi A (2020) Hypercoagulability of COVID-19 patients in intensive care unit: a report of thromboelastography findings and other parameters of hemostasis. J Thromb Haemost 18(7):1738-1742. https://doi. org/10.1111/jth. 14850

3. Connors JM, Levy JH (2020) Thromboinflammation and the hypercoagulability of COVID-19. J Thromb Haemost 18(7):1559_ 1561. https://doi.org/10.1111/jth.14849

4. Connors J, Levy J (2020) COVID-19 and its implications for thrombosis and anticoagulation. Blood 135(23):2033-2040. https://doi.org/10.1182/blood.2020006000/1725756/blood.20200 06000.pdf

5. Spiezia L, Boscolo A, Poletto F, Cerruti L, Tiberio I, Campello E, Navalesi P, Simioni P (2020) COVID-19-related severe hypercoagulability in patients admitted to intensive care unit for acute respiratory failure. Thromb Haemost 120(6):998-1000. https:// doi.org/10.1055/s-0040-1710018

6. Levi M, van der Poll T (2010) Inflammation and coagulation. Crit Care Med 38(2 Suppl):S26-34. https://doi.org/10.1097/ CCM.0b013e3181c98d21

7. Levi M, Keller TT, Gorp EV, Cate H (2003) Infection and inflammation and the coagulation system. Cardiovasc Res 60(1):26-39. https://doi.org/10.1016/s0008-6363(02)00857-x 
8. Chatterjee S, Sengupta T, Majumder S, Majumder R (2020) COVID-19: a probable role of the anticoagulant Protein $S$ in managing COVID-19-associated coagulopathy. Aging. https:// doi.org/10.18632/aging.103869

9. Zohre Khodamoradi SSB, Shirazi FKH, Kouhi P (2020) COVID19 and acute pulmonary embolism in postpartum patient. Emerg Infect Dis 26(8):1937-1939

10. Leisman DE, Deutschman CS, Legrand M (2020) Facing COVID19 in the ICU: vascular dysfunction, thrombosis, and dysregulated inflammation. Intensive Care Med 46(6):1105-1108. https://doi. org/10.1007/s00134-020-06059-6

11. Griffin DO, Jensen A, Khan M, Chin J, Chin K, Saad J, Parnell R, Awwad C, Patel D (2020) Pulmonary embolism and increased levels of d-dimer in patients with coronavirus disease. Emerg Infect Dis 26(8): 1941-1943

12. Yin K, Agrawal DK (2014) Vitamin D and inflammatory diseases. J Inflamm Res 7:69-87. https://doi.org/10.2147/JIR.S63898

13. Rhodes JM, Subramanian S, Laird E, Griffin G, Kenny RA (2020) Perspective: Vitamin D deficiency and COVID-19 severity-plausibly linked by latitude, ethnicity, impacts on cytokines, ACE2 and thrombosis. J Intern Med. https://doi.org/10.1111/joim.13149

14. Mohammad S, Mishra A, Ashraf MZ (2019) Emerging role of vitamin $\mathrm{d}$ and its associated molecules in pathways related to pathogenesis of thrombosis. Biomolecules. https://doi. org/10.3390/biom9110649

15. Sanyaolu A, Okorie C, Marinkovic A, Patidar R, Younis K, Desai P, Hosein Z, Padda I, Mangat J, Altaf M (2020) Comorbidity and its Impact on Patients with COVID-19. SN Compr Clin Med 2(8):1069-1076. https://doi.org/10.1007/s42399-020-00363-4

16. Liu K, Chen Y, Lin R, Han K (2020) Clinical features of COVID19 in elderly patients: a comparison with young and middleaged patients. J Infect 80(6):e14-e18. https://doi.org/10.1016/j. jinf.2020.03.005

17. Kang SJ, Jung SI (2020) Age-related morbidity and mortality among patients with COVID-19. Infect Chemother 52(2):154164. https://doi.org/10.3947/ic.2020.52.2.154

18. Nakashima A, Yokoyama K, Yokoo T, Urashima M (2016) Role of vitamin $\mathrm{D}$ in diabetes mellitus and chronic kidney disease. World J Diabetes 7(5):89-100. https://doi.org/10.4239/wjd.v7.i5.89

19. Andersen LB, Przybyl L, Haase N, von Versen-Hoynck F, Qadri F, Jorgensen JS, Sorensen GL, Fruekilde P, Poglitsch M, Szijarto I, Gollasch M, Peters J, Muller DN, Christesen HT, Dechend R (2015) Vitamin D depletion aggravates hypertension and target-organ damage. J Am Heart Assoc. https://doi.org/10.1161/ JAHA.114.001417

20. Gallagher JC (2013) Vitamin D and aging. Endocrinol Metab Clin North Am 42(2):319-332. https://doi.org/10.1016/j. ecl.2013.02.004

21. Paul Lips KDC, Lamberg-Allardt C, Bischoff-Ferrari HA, Barbara O-P, Stepan J, Fuleihan G-H, Bouillon R (2019) Current vitamin D status in European and Middle East countries and strategies to prevent vitamin D deficiency: a position statement of the European Calcified Tissue Society. Eur J Endocrinol 180:P23-P54

22. Malinovschi A, Masoero M, Bellocchia M, Ciuffreda A, Solidoro P, Alessio Mattei A, Mercante L, Heffler E, Rolla G, Bucca C (2014) Severe vitamin D deficiency is associated with frequent exacerbations and hospitalization in COPD patients. Respir Res 15(131):1-8

23. Kim HJ, Jang JG, Hong KS, Park JK, Choi EY (2015) Relationship between serum vitamin $\mathrm{D}$ concentrations and clinical outcome of community-acquired pneumonia. Int J Tuberc Lung Dis 19(6):729-734. https://doi.org/10.5588/ijtld.14.0696

24. Naghshtabrizi B, Borzouei S, Bigvand P, Seifrabiei MA (2017) Evaluation of the relationship between serum 25-hydroxy vitamin $\mathrm{D}$ and hypertension in hamadan iran - a case control study. J Clin Diagn Res. https://doi.org/10.7860/JCDR/2017/25522.10187
25. Ilie PC, Stefanescu S, Smith L (2020) The role of vitamin D in the prevention of coronavirus disease 2019 infection and mortality. Aging Clin Exp Res 32(7):1195-1198. https://doi. org/10.1007/s40520-020-01570-8

26. Laird E, Rhodes J, Kenny RA (2020) Vitamin D and inflammation: potential implications for severity of Covid-19. Ir Med J 113(5):81

27. Ashu Rastogi AB, Khare N, Suri V, Yaddanapudi N, Naresh Sachdeva GDP, Malhotra P (2020) Short term, high-dose vitamin D supplementation for COVID-19 disease: a randomised, placebo-controlled, study (SHADE study). Postgrad Med J. https://doi.org/10.1136/postgradmedj-2020-139065)

28. Marta Entrenas Castillo LMEC, Barriosa JMV, Díazb JFA, Miranda JL, Bouillon R, Gomez JMQ (2020) Effect of calcifediol treatment and best available therapy versus best available therapy on intensive care unit admission and mortality among patients hospitalized for COVID-19: a pilot randomized clinical study. J Steroid Biochem Mol Biol 203:105751

29. Han JE, Jones JL, Tangpricha V, Brown MA, Brown LAS, Hao L, Hebbar G, Lee MJ, Liu S, Ziegler TR, Martin GS (2016) High dose vitamin D administration in ventilated intensive care unit patients: a pilot double blind randomized controlled trial. J Clin Transl Endocrinol 4:59-65. https://doi.org/10.1016/j. jcte.2016.04.004

30. Burt LA, Billington E, Rose MS, Raymond DA, Hanley DA, Boyd SK (2019) Effect of high-dose vitamin D supplementation on volumetric bone density and bone strength a randomized clinical trial. JAMA 322(8):736-745

31. Ahmed A, Siman-Tov G, Hall G, Bhalla N, Narayanan A (2019) Human antimicrobial peptides as therapeutics for viral infections. Viruses. https://doi.org/10.3390/v11080704

32. Zhang Y, Leung DY, Richers BN, Liu Y, Remigio LK, Riches DW, Goleva E (2012) Vitamin D inhibits monocyte/macrophage proinflammatory cytokine production by targeting MAPK phosphatase-1. J Immunol 188(5):2127-2135. https:// doi.org/10.4049/jimmunol.1102412

33. Sanchez-Niño M-D, Bozic M, Córdoba-Lanús E, Valcheva P, Gracia O, Ibarz M, Fernandez E, Navarro-Gonzalez JF, Ortiz A, Valdivielso JM (2012) Beyond proteinuria: VDR activation reduces renal inflammation in experimental diabetic nephropathy. Am J Physiol Renal Physiol 302:F647-F657

34. Riek AE, Oh J, Sprague JE, Timpson A, delasFuentes L, BernalMizrachi L, Schechtman KB, Bernal-Mizrachi C (2012) Vitamin D suppression of endoplasmic reticulum stress promotes an antiatherogenic monocyte/macrophage phenotype in type 2 diabetic patients. J Biol Chem 287(46):38482-38494. https:// doi.org/10.1074/jbc.M112.386912

35. Helming L, Bo"se J, Ehrchen J, Schiebe S, Frahm T, Geffers R, Probst-Kepper M, Balling R, Lengeling A (2005) 1,25-dihydroxyvitamin D3 is a potent suppressor of interferon $\gamma$-mediated macrophage activation. Blood 106:4351-4358

36. Jeffery LE, Burke F, Mura M, Zheng Y, Qureshi OS, Hewison M, Walker LS, Lammas DA, Raza K, Sansom DM (2009) 1,25-Dihydroxyvitamin D3 and IL-2 combine to inhibit $\mathrm{T}$ cell production of inflammatory cytokines and promote development of regulatory T cells expressing CTLA-4 and FoxP3. J Immunol 183(9):5458-5467. https://doi.org/10.4049/jimmunol.0803217

37. Heine G, Niesner U, Chang HD, Steinmeyer A, Zugel U, Zuberbier T, Radbruch A, Worm M (2008) 1,25-dihydroxyvitamin $\mathrm{D}(3)$ promotes IL-10 production in human B cells. Eur J Immunol 38(8):2210-2218. https://doi.org/10.1002/eji.200838216

38. Grant WB, Lahore H, McDonnell SL, Baggerly CA, French CB, Aliano JL, Bhattoa HP (2020) Evidence that vitamin D supplementation could reduce risk of influenza and covid-19 infections and deaths. Nutrients. https://doi.org/10.3390/nu120 40988 
39. Koyama T, Shibakura M, Ohsawa M, Kamiyama R, Hirosawa S (1998) Anticoagulant effects of 1alpha,25-dihydroxyvitamin D3 on human myelogenous leukemia cells and monocytes. Blood 92:160-167

40. Mai Ohsawa M, Koyama T, Yamamoto K, Hirosawa S, Kamei S, Kamiyama R (2000) 1, alpha, 25-Dihydroxyvitamin D3 and Its potent synthetic analogsdownregulate tissue factor and upregulate thrombomodulin expression in monocytic cells, counteracting the effects of tumor necrosis factor and oxidized LDL. Circulation 102(23):2867-2872

41. Martinez-Moreno JM, Herencia C, Oca AM, Munoz-Castaneda JR, Rodriguez-Ortiz ME, Diaz-Tocados JM, Peralbo-Santaella E, Camargo A, Canalejo A, Rodriguez M, Velasco-Gimena F, Almaden Y (2016) Vitamin D modulates tissue factor and protease-activated receptor 2 expression in vascular smooth muscle cells. FASEB J 30(3):1367-1376. https://doi.org/10.1096/fj.15272872

42. Topaloglu O, Arslan MS, Karakose M, Ucan B, Ginis Z, Cakir E, Akkaymak ET, Sahin M, Ozbek M, Cakal E, Delibasi T (2015) Is there any association between thrombosis and tissue factor pathway inhibitor levels in patients with vitamin D deficiency? Clin Appl Thromb Hemost 21(5):428-433. https://doi. org/10.1177/1076029613509477

43. Khademvatani K, Seyyed-Mohammadzad MH, Akbari M, Rezaei Y, Eskandari R, Rostamzadeh A (2014) The relationship between vitamin D status and idiopathic lower-extremity deep vein thrombosis. Int J Gen Med 7:303-309. https://doi.org/10.2147/IJGM. S64812

44. Wu WX, He DR (2018) Low vitamin D levels are associated with the development of deep venous thromboembolic events in patients with ischemic stroke. Clin Appl Thromb Hemost 24(9 suppl):69S-75S. https://doi.org/10.1177/1076029618786574

45. Blondon M, Biver E, Braillard O, Righini M, Fontana P, Casini A (2019) Thrombin generation and fibrin clot structure after vitamin D supplementation. Endocr Connect 8(11):1447-1454. https://doi. org/10.1530/EC-19-0429

46. Beer T, Venner PM, Ryan CW, Petrylak DP, Chatta G, Ruether JD, Chi KN, Curd JG, DeLoughery TG (2006) High dose calcitriol may reduce thrombosis in cancer patients. Br J Haematol 135:392-394

47. Lindqvist PG, Epstein E, Olsson H (2009) Does an active sun exposure habit lower the risk of venous thrombotic events? A
D-lightful hypothesis J Thromb Haemost 7(4):605-610. https:// doi.org/10.1111/j.1538-7836.2009.03312.x

48. Hejazi ME, Modarresi-Ghazani F, Hamishehkar H, MesgariAbbasi M, Dousti S, Entezari-Maleki T (2017) The effect of treatment of vitamin d deficiency on the level of P-selectin and hs-CRP in patients with thromboembolism: a pilot randomized clinical trial. J Clin Pharmacol 57(1):40-47. https://doi.org/10.1002/ jcph.774

49. Jose RJ, Manuel A (2020) COVID-19 cytokine storm: the interplay between inflammation and coagulation. Lancet Respir Med 8(6):e46-e47. https://doi.org/10.1016/s2213-2600(20)30216-2

50. Lodigiani C, Iapichino G, Carenzo L, Cecconi M, Ferrazzi P, Sebastian T, Kucher N, Studt JD, Sacco C, Alexia B, Sandri MT, Barco S, Humanitas C-TF (2020) Venous and arterial thromboembolic complications in COVID-19 patients admitted to an academic hospital in Milan, Italy. Thromb Res 191:9-14. https://doi. org/10.1016/j.thromres.2020.04.024

51. Lemke G, Silverman GJ (2020) Blood clots and TAM receptor signalling in COVID-19 pathogenesis. Nat Rev Immunol 20(7):395396. https://doi.org/10.1038/s41577-020-0354-x

52. Tang N, Bai H, Chen X, Gong J, Li D, Sun Z (2020) Anticoagulant treatment is associated with decreased mortality in severe coronavirus disease 2019 patients with coagulopathy. J Thromb Haemost 18(5):1094-1099. https://doi.org/10.1111/jth.14817

53. Paranjpe S, Fuster V, Lala A, Russak AJ, Glicksberg BS, Levin MA, Charney AW, Narula J, Fayad ZA, Bagiella E, Zhao S, Nadkarni GN (2020) Association of treatment dose anticoagulation with in-hospital survival among hospitalized patients with COVID-19. J Am Coll Cardiol 76:122-129

54. Stoichitoiu LE, Pinte Balea LMI, Nedelcu V, Badea C, Baicus C (2020) Anticoagulant protein S in COVID-19: low activity, and associated with outcome. Rom J Intern Med. https://doi. org/10.2478/rjim-2020-0024

Publisher's Note Springer Nature remains neutral with regard to jurisdictional claims in published maps and institutional affiliations. 